University of Tulsa College of Law

TU Law Digital Commons

Articles, Chapters in Books and Other Contributions to Scholarly Works

1998

\title{
The Total S.A. Case: Meaning of "Investment" Under the ILSA
}

Rex Zedalis

Follow this and additional works at: http://digitalcommons.law.utulsa.edu/fac_pub

Part of the Law Commons

This article is reproduced with permission from the July 1998 issue of the American Journal of International Law (C) 2013 American Society of International Law. All rights reserved.

\section{Recommended Citation}

92 Am. J. Intl. L. 539 (1998).

This Article is brought to you for free and open access by TU Law Digital Commons. It has been accepted for inclusion in Articles, Chapters in Books and Other Contributions to Scholarly Works by an authorized administrator of TU Law Digital Commons. For more information, please contact daniel-bell@utulsa.edu. 


\section{CURRENT DEVELOPMENTS}

\section{The Total S.A. CASE: MEANING OF "INVESTMENT" UNDER THE ILSA}

\section{INTRODUCTION}

On March 7, 1995, Conoco oil company of Houston, Texas, announced that it had entered into a contract with Iran to have a Netherlands-based affiliate assist in the development of the Sirri Island oil field. ${ }^{1}$ In response, the Clinton administration issued Executive Order No. 12,957, prohibiting participation by U.S. entities in the development of Iranian petroleum resources. ${ }^{2}$ Eventually, Conoco withdrew from its contract, ${ }^{3}$ but in early May of 1995 the administration stepped up its pressure on Iran by issuing Executive Order No. 12,959, prohibiting U.S. entities from using foreign entities they owned or controlled to make investments in or conduct trade transactions with Iran. ${ }^{4}$ On July 13 of that year, the French oil company Total S.A. entered into an agreement with Iran to replace Conoco in developing the Sirri Island field, ${ }^{5}$ and over the next several months Iran struck nearly a dozen petroleum development agreements worth in excess of $\$ 50$ million each with other foreign oil companies. ${ }^{6}$ Within a couple of months, both Houses of the U.S. Congress took up consideration of proposals to complicate Iran's ability to develop its hydrocarbon resources. ${ }^{7}$ By the end of 1995 , the proposals, which even extended to wholly foreign entities organized and operating outside the United States, had come to include Libya as well. ${ }^{8}$ Final passage of one of the proposals, specifically, H.R. 3107, took place in the Senate and the House in July $1996 . .^{9}$ It was signed into law as the Iran and Libya Sanctions Act (ILSA) on August $5 .^{10}$

\footnotetext{
' See Agis Salpukas, Iran Signs Oil Deal With Conoco: First Since 1980 Break With U.S., N.Y. Times, Mar. 7, 1995, at $\mathrm{Al}$.

${ }^{2}$ See 60 Fed. Reg. 14,615 (Mar. 17, 1995).

${ }^{3}$ See Douglas Jehl, Oil Concern Ends Deal With Iran as President Acts, N.Y. Times, Mar. 15, 1995, at Al (contract was contingent on approval of Conoco's board, which insisted that the U.S. Government have no objections to proceeding).

4 See 60 Fed. Reg. 24,757 (May 9, 1995) (prohibiting U.S. goods, technology or services from being directly or indirectly supplied to Iran; and prohibiting U.S. persons from dealing in Iranian goods, or from approving, facilitating or financing any owned or controlled foreign entity's engagement in conduct prohibited to U.S. persons). For regulations implementing Executive Order Nos. 12,957 and 12,959 in regard to Iran, see 31 C.F.R. $\$ 560$, especially $\$ 560.204, .207, .209$ (1997).

"See Iranian Negotiations, N.Y. TIMES, Apr. 28, 1995, at D5 (announcement by Iran of negotiations with Total and Royal Dutch Shell to develop Sirri Island field abandoned by Conoco); Shell Decides Not to Develop Iran Oilfields, N.Y. Times, July 4, 1995, at 46 (Royal Dutch Shell withdraws, leaving only Total).

"See H.R REP. No. 104-523(I) (1996), reprinted in 1996 U.S.C.C.A.N. 1296, 1299.

${ }^{7}$ On the Senate side, S. 1228, 104th Cong., was introduced by Senator Alfonse D'Amato on September 8 , 1995. On the House side, the initial proposal was H.R. 2458, 104th Cong., introduced by Congressman Benjamin A. Gilman on October 12, 1995. D'Amato's proposal was adopted by the Senate on December 20, 1995. Gilman's initial proposal was replaced on March 19, 1996, by his H.R. 3107, 104th Cong. After deliberation and amendment, the House passed H.R. 3107 on June 19, 1996.

"See S. 1228 (as passed by Senate), $\$ 11,104$ th Cong.; H.R. 3107 (as passed by House), 104th Cong., titled "Iran and Libya Sanctions Act of 1996."

"See 142 CoNG. REC. S7917 (passage in Senate, July 16, 1996); 142 CoNG. REC. H8125-27, H8245 (passage in House and enrollment, July 23, 1996).

"' See Pub. L. No. 104-172, 110 Stat. 1541 (1996) [hereinafter ILSA]. It should be noted that, because the Senate acted first to adopt proposed legislation and then amended H.R. 3107, the bill that was ultimately adopted, the legislation signed into law by the President, is often referred to as the D'Amato Act.
} 
The ILSA contains several interesting provisions," perhaps none more so than its prohibition on "investment[s]."12 Since Iran holds the world's second largest reserves of natural gas, ${ }^{13}$ the interest of international oil and gas companies in making investments in hydrocarbon development in that country is obvious. This interest, in conjunction with the earlier success of Total S.A. in replacing Conoco in exploiting the Sirri Island field, undoubtedly contributed to the French oil company's striking a $\$ 2$ billion deal with Iran on September 28, 1997, to develop natural gas reserves in the offshore South Pars field. ${ }^{14}$ That transaction precipitated immediate debate within the Clinton administration about the imposition of sanctions under the ILSA ${ }^{15}$ against Total and the other companies involved. ${ }^{16}$ While at the time this commentary was written, it was not yet clear if the deal involving Total met the threshold requirement of an "investment" essential to trigger sanctions, the case provides an ideal opportunity to examine the precise bounds of that concept.

Virtually all the debate regarding the contract between Total and Iran has revolved around the pros and cons of extraterritorial application of U.S. law. ${ }^{17}$ In some respects, this is but a continuation of a long-standing European and American controversy, renewed most recently in the context of the Helms-Burton legislation. ${ }^{18}$ Another problematical matter, the meaning of the term "investment" as used in the ILSA's basic sanctions provision, section 5, is addressed here. My inquiry suggests that the term "investment" raises questions about two sorts of legal commitments connected with Iran: contracts to provide services to the oil and gas industry, and petroleum resource development agreements. Each of these will be taken up in turn. I will focus on whether either of these basic forms of commitment, or any agreement to provide financing for them, falls within the ambit of an investment subject to sanctions. Especial reference to section $14(9)$ of the Act, which defines "investment," will be required.

With respect to service contracts, part II of this commentary contends that the language of the ILSA is fraught with ambiguity. The relationships between the term "investment"

\footnotetext{
"Essentially, as regards Iran, it requires the President to impose sanctions, ranging from denial of ExportImport Bank privileges to limitations on rights of export and import, see id. $\$ \$ 5(\mathrm{a}), 6(1)-(6)$, whenever the President determines that an investment has occurred that "significantly contributed to the enhancement of Iran's ability to develop [its] petroleum resources," id. It defines "develop" as including a variety of activities from exploration to transportation by pipeline, $i d$. $\$ 14(4)$. Sanctions need not be imposed in certain exceptional cases, $i d$. $\$ 5(f)$, or in the event that the President exercises the Act's waiver authority, which is based on pursuit of the U.S. national interest, $i d . \$ 9$ (c) (1). Authority also exists for choosing to handle the objectionable investment through multilateral means, but only when a country with jurisdiction over the offending party is willing to impose measures inhibiting the transaction with Iran, id. $\S 4$ (c). Sanctions can also be delayed under the Act to allow the President to attempt to get another nation vested with jurisdiction to end an objectionable investment, id. $\$ 9(\mathrm{a})$.

${ }^{12}$ See ILSA, supra note $10, \$ 5$.

${ }^{13}$ See Youssef M. Ibrahim, Energy Industry Lured by Vast Gulf Deposits, N.Y. TIMES, Sept. 30, 1997، at A9.

${ }^{14}$ See Roger Cohen, France Scoffs at U.S. Protest over Iran Deal, N.Y. TIMES, Sept. 30, 1997, at A1.

${ }^{15}$ For early French objections, see Youssef M. Ibrahim, French Oil Official Asks if U.S. Law Reacites Iran, N.Y. TIMES, Oct. 6, 1997, at A6. For debate within the Clinton administration, see Gazprom Withdraws from Agreement with Ex-Im Bank Following Hill Criticism, 14 Int'l Trade Rep. (BNA) 2241 (Dec. 24, 1997); U.S., France to Hold New Talks on Iran Investment Deal, Official Says, 15 Int'1 Trade Rep. (BNA) 18 (Jan. 18, 1998); EU, United States Remain Upbeat After Failing to Agree on Cuba, Iran-Libja, id. at 186 (Feb. 4, 1998); Bhushan Bahree \& Thomas Kamm, Total Seeks More Pacts With Iran, Despite U.S., WALL ST. J., Mar. 17, 1998, at A13.

${ }^{16}$ See Craig R. Whitney, New U.S. Envoy to Paris Ponders His Stormy Star, N.Y. Times, Oct. 1, 1997, at A3 (indicating that the Russian company Gazprom and the Malaysian state-owned company Petronas were participating with Total S.A.).

${ }_{17}$ See, e.g., 14 Int'l Trade Rep. (BNA) 1735 (Oct. 8, 1997) (EU Trade Commissioner Sir Leon Brittan asking United States to acknowledge Total's right to invest under international law).

${ }^{18}$ For the ongoing dispute regarding Helms-Burton, see Andreas F. Lowenfeld, Congress and Cula: The HelmsBurton Act, 90 AJIL 419 (1996); Brice M. Clagett, Title III of the Helms-Burton Act Is Consistent with International Law, id. at 434; Peter Glossop, Recent US Trade Restriction Affecting Cuba, Iran and Libya-a View from Outside the US, 15 J. ENERGY \& NAT. RESOURCES L. 212 (1997). For one perspective on the history of U.S. economic sanctions generally, see William Fox, United States and Economic Sanctions: One American Perspective, id. at 387. For the European response to both Helms-Burton and the ILSA, see Bruno Cova, The European Response to U.S. Extraterritorial Legislation, 10 OIL \& GAS L. \& TAX'N REv. 353 (1997).
} 
in section 14(9) and other provisions of the Act suggest that service contracts involving a hands-on part in actually getting petroleum from the ground to market can be argued as within the reach of the Act. Nonetheless, there is reason to believe that Congress may have intended service contracts of all sorts to fall outside the Act. However, undertakings simply to provide the financial backing to support service contracts are not affected by the Act. With respect to petroleum resource development agreements, part III argues that the basic development agreement itself clearly lies within the direct aim of what the Act targets as subject to sanctions. On financing development agreements, and various circuitous methods of participating in the benefits incident to development agreements, the ILSA seems to be slightly less clear. The best available evidence, though, strongly suggests that financing falls outside what the Act punishes, just as with service contracts. The evidence also provides solid support for excepting from sanctions one who is guilty of nothing more than an ownership or control connection with another entity violating the Act. Though it is somewhat uncertain, the direction by one company to a subsidiary or affiliate to make an "investment" inappropriate under the ILSA appears to trigger the potential for sanctions on both the acting and the directing entities.

\section{ARE OIl Field Service Contracts Subject to Sanctions?}

\section{Service Contracts}

The last sentence of section 14(9) of the ILSA, in defining an "investment" subject to sanctions under section 5, explicitly excludes contracts to sell or purchase "goods, services, or technology." "Subsection 14(9) (A), however, indicates that such an investment does include contracts of "responsibility for" development of petroleum resources in Iran or Libya, and contracts of "general supervision and guarantee of" performance of these contracts. ${ }^{20}$ Explaining the language of that subsection, the House Ways and Means Committee Report indicates that it was intended to subject to sanctions contracts for "the provision of managerial services entailing overall responsibility for the development of Iranian or Libyan petroleum resources."21 From statements appearing earlier in the Report, it seems clear that section 14(9)'s exclusionary last sentence was designed to remove from exposure to sanctions all sales of goods and technology, including sales of items that could aid in the development of petroleum resources. ${ }^{22}$

If the intent was for things like seismographic, drilling and pipeline services to fall outside the reach of the ILSA, Congress succeeded in putting together a woefully inadequate and ambiguous statutory configuration. The legislative history quite explicitly declares "managerial services" to be included within "investment," yet services generally are to be excluded, which results in an inconsistency. In many instances, seismographic, drilling, pipeline and other such services integral to the discovery, lifting and supply of petroleum can be seen as performed under contracts establishing the provider's "responsibility for" development of petroleum resources. The contractual commitment fixes a duty on providers to play their role in getting oil or gas to market. Thus, an "investment" exists, and it is subject to sanctions in accordance with the Act.

${ }^{1 "}$ See ILSA, supra note 10, \$14(9).

in See id. $\$ 14(9)(\mathrm{A})$.

$"$ See H.R. REP. No. 104-523(II) (1996), reprinted in 1996 U.S.C.C.A.N. 1311, 1322.

${ }^{22}$ See id. at 1317 ("the Committee did not believe it was wise to include a requirement in the bill that the President sanction trade with Iran" and it would be difficult and unworkable to monitor "trade with Iran, especially in common goods like drill pipe and drill bits"). 
Several specific pieces of evidence operate to complicate any congressional objective of removing all service contracts from the scope of the ILSA. To begin with, subsection $14(9)$ (A)'s reference to investment as including a contract establishing responsibility for "development" of petroleum resources is preceded by section 14(4)'s definition of "development" as the "exploration for, or the extraction, refining, or transportation by pipeline of, petroleum resources." 23 Thus, seismographic activity, drilling and transportation by pipeline, as well as other services represented by physical or mental involvement in field activities ranging from discovery to supply, could well be seen as constituting "development." Clearly, legal advice, accounting and personnel services also contribute to the success or failure of a development effort. But such services do not involve their provider in exploration, extraction, refining or transportation, and therefore fall outside the ambit of the Act.

Further, section 5(a) itself, the basic Iran sanctions provision, states that it is targeted at investments large enough to "directly and significantly contribute to the enlancement of Iran's ability to develop petroleum resources." ${ }^{24}$ Legal, accounting and personnel services, for example, that are provided to an entity involved in a contractual commitment to help Iran tap its oil and gas deposits undoubtedly "contribute," albeit in a roundabout way, to that nation's ability to develop petroleum resources. Nonetheless, the requirement in section 5 (a) that the investment must "directly and significantly" contribute to the development efforts supports the view that the ILSA permits distinctions to be drawn between various services. The result is to characterize only those that fail so to contribute in an immediate and proximate fashion as within the exclusionary language of the last sentence of section 14(9), and to subject to sanctions as investments all those in which the provider is involved in the physical or mental activities of discovery, drilling, lifting, refining or supply.

Finally, rationality itself provides some support for interpreting the term "investment" so as to encompass activities like seismographic, drilling and pipeline transportation services. Juxtaposing the Act's blanket exclusion in the last sentence of section 14(9) and the legislative history's reference to "managerial services" as being included within the ILSA's coverage reveals the peculiarity of reading the services exclusion as prohibiting one from doing indirectly (i.e., through managing another) what one is permitted to do directly (i.e., through actually performing the service). What sensible enterprise would contract to provide what is prohibited, that is, to oversee another's provision of services, when it has the option of providing the service itself? Admittedly, because the reference to "managerial services" is followed immediately by the words "entailing overall responsibility," ${ }^{25}$ there might be some inclination to regard the reference as dealing only with the service of managing the entire development project. Militating against this inclination, however, are the more segmented view of a resource project reflected in the Act's definition of "development" 26 and the logical outcome that if a prohibition applies only to supervision of an entire project, it will simply be broken into separate parts.

\section{Financing of Service Contracts}

In view of the openings for argument left by Congress as regards the inclusion of oil field service contracts within the sanctions provisions of the ILSA, how has it addressed contracts for financing such services? Again, section 14(9) (A) speaks of a covered investment as a contract that includes "responsibility for" petroleum development. ${ }^{27}$ Is it

${ }^{23}$ See ILSA, supra note $10, \S 14(4)$.

${ }^{24}$ See id. $\$ 5(\mathrm{a})$.

${ }^{25}$ See supra note 21 and corresponding text.

${ }^{26}$ See supra note 23 and corresponding text.

${ }^{27}$ See supra note 20 and corresponding text. 
conceivable that by underwriting the financial dimension of a contract to provide something like seismographic services, one engages in conduct subject to sanctions?

As already observed, petroleum "development" is defined to extend to mere exploration. ${ }^{28}$ Thus, in the event a contract to provide financing can be considered as resulting in the financier's taking on "responsibility for" development, an investment subject to sanctions can be said to exist. A more restrictive reading of the concept of "responsibility" would require one actually to undertake the exploration, extraction, refining or supply. Merely providing aid or assistance that allows another to undertake such activity would be insufficient. Section 6(4) of the Act, however, in its description of the sanctions available to the President to combat unacceptable investment, speaks of particular measures that "may be used against a sanctioned person that is a financial institution." 29 The implication is that, if financial institutions are subject to sanctions for conduct in which they have engaged, perhaps the Act even encompasses conduct in which they engage on a regular and routine basis-the provision of loans and other financial services.

Despite the ambiguities inherent in both "responsibility for" and the language just quoted from section $6(4)$ of the ILSA, Congress's intent regarding the financing of contracts to provide services comes through much more clearly than it does regarding the inclusion of actual oil field services within the ambit of investment. The last sentence of section 14(9), which contains the previously discussed broad exclusion for services, applies that exclusion not only to contracts to sell services, but also to the "financing of a contract" to sell them. On the narrow issue of how financing is treated, what prevents this rather explicit language from being confused by other relevant language in the Act is the legislative history leading to its adoption.

H.R. 3107, the bill that was eventually enacted as the ILSA, provided, as originally introduced, that "investment" included contracts to finance development of petroleum resources. ${ }^{30}$ It also defined "development" as meaning exploration, as well as extraction, refining and transportation by pipeline, presaging the definition employed by the ILSA. ${ }^{31}$ When the bill was taken up by the House Ways and Means Committee, the language of inclusion for financing was completely removed and replaced by the exclusionary language now appearing in the last sentence of section 14(9) of the Act. ${ }^{32}$ Though nothing is said in the Ways and Means Committee Report about the motivation underpinning the change, ${ }^{33}$ it is apparent that the committee considered the amended version it was reporting to the full House as not covering financing for, at least, sales of services or goods and technology. ${ }^{34}$ Given Congress's intent to have the Act leave aside the financing of oil field service contracts, the reference in section $6(4)$ of the ILSA to punitive measures taken against "a person that is a financial institution" must signify that certain other types of conduct engaged in by a financial institution can be subject to sanctions. ${ }^{35}$ However, actions to underwrite the economic side of something like a seismographic services contract are not included.

\footnotetext{
${ }^{2 \times}$ See supra notes 23-24 and corresponding text.

29 See ILSA, supra note $10, \$ 6(4)$.

See H.R. 3107 (Mar. 19, 1996), supra note 7, §13(10)(D) (i).

(1) See id. $\$ 13(5)$.

"See H.R. 3107, 104th Cong. (as adopted by the Ways and Means Comm., June 14, 1996), \$14(9), last sentence.

3 See H.R. REP. NO. 104523(II), supra note 21.

34 See, e.g., id. at 1317 (describing "investment" under $\$ 5$ of the Act as "not deal[ing] with financing or trade"; and the definition of "investment" under $\$ 14$ as not subjecting "the entry into, performance of, or financing of contracts to sell or purchase goods, services, or technology" to the strictures of the legislation). On whether financing the natural resource development agreement itself is considered a covered "investment," see part III of this commentary infra.

${ }^{5}$ See infra note 43 and corresponding text.
} 


\section{Are Resource Development Agreements Subject to Sanctions?}

\section{Financing of Development Agreements}

The foundation from which any oil field service contract springs is the development agreement, be it a concession, a joint operating agreement, a production-sharing agreement, a buy-back agreement, or some other variant that allocates shares of the management, work or profits between the international operator and the host country. In keeping with the fact that a contract to finance an oil field service agreement has just been characterized as falling beyond the reach of the ILSA's notion of an "investment" subject to sanctions, it may be appropriate to begin the present discussion with some observations about the Act's treatment of contracts to finance the natural resource development agreement. On that score, financing provided to an enterprise that has entered into a natural resource agreement with Iran or Libya is qualitatively different from financing to one that merely performs an oil field service. The former places the financier in the position of underwriting an entity with a claim to the oil or gas, or profits therefrom, that may be produced. The latter, however, involves support for one that may have no such claim. In view of that distinction, it is understandably tempting to read the exclusion in the last sentence of section 14(9) of the Act as one that does not extend to the financing of the basic underlying development agreement.

There can be no doubt that some slight ambiguity exists regarding contracts financing the natural resource development agreement itself. Congress cast section 14(9)'s exclusion of financing in terms of financing for goods, services or technology. ${ }^{3 i}$ Nothing is said about financing for the foundational agreement upon which other financing agreements rest. Further, the exclusion in section 14(9) found its way there, as indicated previously, ${ }^{37}$ by virtue of an amendment deleting language that defined a contract to finance the development of petroleum resources as an investment subject to sanctions. Is the implication from this that Congress considered it permissible to finance all things, irrespective of the limited wording of the exclusion, or only those things expressly enumerated?

The hearings held by the Subcommittee on International Trade of the House Ways and Means Committee, in conjunction with the deliberations that resulted in the removal from H.R. 3107 of the language defining financing as "investment," provide insight into the change. At those hearings, officials from the Office of the U.S. Trade Representative and the Department of the Treasury made known their view that it was inadvisable to include financing operations within the notion of investment. ${ }^{38}$ No opposition to this view was expressed by the members of the subcommittee. Then, when the amended version containing the narrowly drawn exclusion referencing only goods, services and technology was taken up by the full House, the principal sponsors of the legislation made several statements indicating that financing would not be covered by what ultimately went on to become the ILSA. ${ }^{39}$ Indeed, at one juncture during the floor debate preceding the House's passage of the legislation, Congressman Sam Gejdenson, of Connecticut, indicated that he had personally sent letters to "banks and economic entities in the G7 countries" informing them that, while the amended version of the legislation reported to the full House no longer defined "investment" as including financing, Congress would closely monitor the lending practices of such institutions and might respond with additional legislation if abuses developed. ${ }^{40}$ Again, no objection was expressed. Further,

${ }^{36}$ See IISA, supra note 10, $\$ 14(9)$, last sentence.

${ }^{37}$ See supra notes 32-34 and corresponding text.

${ }^{38}$ See Iran and Libya Sanctions: Hearings Before the Subcomm. on Trade of the House Comm. on Ways and Means, 104th Cong. at 7, 12, 26, 31-32 (1996) [hereinafter Hearings].

${ }^{39}$ See 142 CONG. REC. H6474, H6476 (1996). For consideration by the full Senate, which is not informative, see id. at S7908 (Kennedy and D'Amato amendment to H.R. 3107) and S7917.

${ }^{40}$ See id. at $\mathrm{H} 6474$. 
as no effort was made in either the subcommittee hearings or the floor debate to distinguish between financing an entire project and financing its separate components, the implication is that both lie outside the reach of the ILSA, despite the exclusionary language of the last sentence of section 14(9) mentioning only financing for goods, services and technology. ${ }^{41}$

\section{Development Agreements and Circuitous Methods of Participation}

With regard to entering into the natural resource development agreement itself, the Act is clear in subjecting such conduct to sanctions. ${ }^{42}$ To the extent that oil field service contracts are in the same position, a certain parallelism thus appears. The work side of the transaction is considered objectionable, but the financing side is not. The really intriguing aspect of the development agreement concerns the use of circuitous methods by entities desirous of participating in an oil and gas development agreement. There seem to be two categories of circuitous methods available to such entities. The first involves avoidance of responsibility for directly performing the obligations of a development agreement by entering into an agreement to create an ownership interest in, or right to participate in the proceeds of, another entity's contract to conduct, supervise or, perhaps, as suggested in part II above, service a natural resource development agreement. The second involves the establishment of an ownership connection with another entity that makes a commitment either to conduct, supervise or service a development agreement, or to acquire an ownership interest in, or right to share in the proceeds of, a contract to conduct, supervise or service an agreement to develop oil and gas resources.

Concerning the first of these two categories, subsections 14(9)(B) and (C) explicitly provide that the term "investment" includes " $[t]$ he purchase of a share of ownership, including an equity interest, in [a petroleum resource] development," and " $[t]$ he entry into a contract providing for the participation in royalties, earnings, or profits in [such a] development, without regard to the form of the participation." Thus, an entity can clearly be subject to punishment for entering into any form of understanding that vests it with a share in the production or profits of a petroleum development project. This would include, for example, understandings spanning the spectrum from those based on the acquisition of rights in traditional oil and gas production and profit-sharing agreements or farm-out agreements, to those taking the form of unconventional, speculative finance arrangements designed to repay and reward, with interests in production or profits, equity infusions supporting a development agreement. In a sense, the observation offered about speculative and creative finance arrangements provides some explanation of why section 6(4) of the Act speaks of financial institutions as being subject to sanctions. ${ }^{43}$ The idea is not to signify that financing is generally an investment subject to sanctions. It is rather to acknowledge that financial institutions may occasionally engage in practices for which the Act provides no tolerance.

Because subsection 14(9) (B) refers to ownership shares as being defined as covered "investment[s]," including those shares considered to be "equity interest[s]," there may be some question whether mere stock or bond ownership qualifies as punishable. Subsection 14(9) (G)'s objection to contracts providing for "participation in . . . profits" of a development project can be read as supporting this approach, especially since stock

\footnotetext{
${ }^{41}$ It should be observed, though, that during the debate on the House floor about the bill, Congressman Berman is reported to have asked Congressman Gilman to comment on the meaning of the \$14(9) definition of "investment." In response, Gilman simply indicated that it "is intended to underscore . . . [the absence] of a trade trigger." See id. at $\mathrm{H} 6476$.

"See ILSA, supra note $10, \$ 14(9)$ (A).

1' See supra note 29 , and text at notes $34-35$ (indicating that the mention of financial institutions does not mean the Act contains a general prohibition on financing).
} 
or bond owners have a right to share in the profits of the entities in question. However, the reports of both the International Relations Committee and the Ways and Means Committee of the House of Representatives make it crystal clear that the intent of the statute is not to characterize what might be described as "portfolio investment" in an entity engaged in punishable activity as conduct that can itself be penalized under the ILSA. ${ }^{44}$ Purchasing a share in another entity's development agreement and acquiring an interest in a contract providing for a right to participate in the rewards of a development agreement are both punishable activities. Simply holding equity or debt interests for income purposes, though, falls beyond the reach of the sanctions provisions of the Act.

As for the second category of circuitous investment methods, that involvirig the use of intermediaries, reference to section $5(c)$ is imperative. It must be observed that section 5(c) applies across the board and not just to the foundational natural resource development agreement. That is to say, the section applies to any activity considered an investment. It identifies the persons subject to sanctions under the ILSA. In not confining itself to U.S. entities, it serves as the basis for all the disputes about extraterritoriality. Those within its reach include both entities that have made a punishable investment, and any successor, or "parent or subsidiary" with actual knowledge of the objectionable conduct, or "affiliate" with such knowledge, if that affiliate is controlled by the entity that made the investment. ${ }^{45}$

Clearly, section 5(c) contains no limit on imposing sanctions on those who actually make, or succeed those who make, an objectionable investment. The references to "parent or subsidiary" and "affiliate" suggest an awareness of the fact that, through ownership-layering or control-layering strategies, entities may seek to sidestep the ILSA's restrictions. This inference should not be taken as implying that a punishable investment entered into by one entity necessarily subjects to sanctions a parent or subsidiary, or a controlled affiliate, with actual knowledge of the investment. Subsections 5 (c) (2) (B) and (C) plainly indicate that, before a parent, subsidiary or controlled affiliate can be penalized, they themselves must "have engaged in" some sort of inappropriate investment. A mere ownership connection with another entity, even when accompanied by knowledge of the other entity's objectionable activity, is insufficient to impute culpability entailing sanctions to one that is not itself engaged in an investment considered inappropriate. Parents cannot be penalized for the acts of controlled subsidiaries or affiliates simply because control is coupled with knowledge.

As originally introduced, H.R. 3107 took a broader approach and permitted sanctions against parents for the actions of subsidiaries and affiliates without requiring more than ownership or control and knowledge. ${ }^{46}$ Objections led the Ways and Means Committee to report the current language to the full House for adoption. ${ }^{47}$ Though it is not entirely clear, in view of the provision of sanctions under subsection $5(\mathrm{c})(2)(\mathrm{B})$, when parents know of their subsidiaries' investments and have themselves "engaged in the activities" of investment, there seems to be good reason to believe that the Act reaches situations in which subsidiaries are used to engage in activity parents wish to avoid. ${ }^{48}$ The implica-

\footnotetext{
${ }^{44}$ See H.R. REP. No. 104-523(I), supra note 6, at 1303 (International Relations Comm.); H.R. REP. No. 104 523(II), supra note 21, at 1318 (Ways and Means Comm.).

${ }^{45}$ See IISA, supra note $10, \$ 5$ (c) (2)(C), speaking of "controlled in fact," which is left undefined.

${ }^{46}$ See H.R. 3107 (Mar. 19, 1996), supra note 7, \$4(b) (4) -(6). Parents were liable if they had "actual knowledge or had reason to know" of objectionable investment activities. Wholly owned subsidiaries were fully liable for the investments of those who owned them. Other subsidiaries and affiliates were liable if, with knowledge or reason to know, they had "engaged in activities which were the basis of [a] determination" of investment.

${ }^{47}$ For the objections to the original version on grounds of one entity's being subject to punishment for conduct of an associated entity, see Hearings, supra note 38, at 7, 13, 21, 30-31. The version of the bill reported by the Ways and Means Committee to the full House substituted what appears in subsections 5 (c) (2)(B) and (C) for the objectionable language in the original bill. See H.R. 3107, supra note 32, \$5(c) (2) (B) \& (C).

${ }^{48}$ See H.R. REP. No. 104523(II), supra note 21, at 1317 (indicating that "purchases or equity interests in a non-Iranian company subject to [\$14 and sanctions]" is permissible, "unless the purchasing party is covered
} 
tion seems to be that parents, by knowingly pursuing objectionable activity through their subsidiaries, evidence fault that can bring sanctions on themselves. Being "engaged in the activities" the IISA punishes encompasses the use of an agent to perform objectionable activity that the principal fears to perform directly.

\section{Consmerations Relevant to Decision Regarding Total S.A.}

The complexities associated with the ILSA's use of the term "investment" will provide lawyers representing businesses interested in ventures in Iran with interpretive challenges. The French oil company Total S.A. may incur sanctions under the Act for assistance it has contracted to provide in the development of Iran's South Pars gas field. The precise nature of Total's commitment will prove instrumental in that regard. In view of the ILSA's waiver provisions, however, the international considerations surrounding the episode may be even more important. To conclude this commentary, I offer some brief reflections on three considerations relevant to the ultimate decision.

The first concerns the irritation sanctions might provoke in European allies. Innumerable sources of discomfiture can already be found in U.S.-European trade relations. These range from growth hormones in beef, to divergent approaches on bribery in international business transactions, to import and investment restrictions designed to protect cultural industries. ${ }^{49}$ While sanctions under extraterritorially applied U.S. law are likely to add a further complication, a variety of natural affinities suggest the impossibility of any rupture in relations. Nonetheless, given the demise of bipolarity, the Europeans may feel easier about voicing their true sentiments concerning what might be seen as American abuse of an unrivaled political dominance. Such statements could open cracks that opportunists among rogue nations might seek to exploit. The end result could be increased difficulty in establishing a U.S.-European consensus on how sensitive world problems should be addressed, both now and in the future.

Second, there is the matter of U.S.-Iranian relations. The recent overture by Iran's President Mohammad Khatami ${ }^{50}$ might be a shrewd deception aimed at gaining a steady inflow of capital for hydrocarbon development so that weapons programs and terrorist activities can continue to be funded. Conversely, it might reflect a plea for a responsive gesture that would strengthen the hand of Islamic moderates in their struggle against the reactionary clerics who have long exerted control over all aspects of political and civic life. In either case, sight should not be lost of the fact that, for nearly twenty years, U.S.-imposed economic isolation has failed to stem the tide of Iranian-sponsored fundamentalist terrorism or discourage investment by foreign entrepreneurs in Iranian business ventures. All along, however, principle has been pursued at the expense of American enterprises and financiers. Given Khatami's recent overture, perhaps the time has come for the United States to switch to a policy of "engagement" with Iran and away from that of "dual containment," which has focused on isolating Iran as well as

by Section 5(c)(2) (B) of the bill which deals with parent-subsidiary relationships"). The implication is that one cannot escape the limitations of the Act by using a subsidiary to accomplish investment the parent refrains from making. Sanctions can be imposed on the subsidiary and the parent if the parent had knowledge and is found to have "engaged in the activities" of investment.

${ }^{4 y}$ See, e.g., EC-Measures Concerning Meat and Meat Products (Hormones), Complaint by the United States, WTO Doc. WT/DS26/R/USA (Aug. 18, 1997) (panel report); EC Plans to Ban U.S. Beef Exports Due to Hormone, Antibiotic Residues, 14 Int'l Trade Rep. (BNA) 2210 (Dec. 24, 1997); U.S., Europe at Loggerheads over Talks to End Bribery in International Transactions, id. at 1985 (Nov. 19, 1997); Rex J. Zedalis, Internationalizing Prohibitions on Foreign Comupt Practices: The OAS Convention and the OECD Revised Recommendatiom, J. WORLD TRADE, Dec. 1997, at 45; Debate on Exceptions, Labor Issues Heats up at OECD Investment Talks, 14 Int'l Trade Rep. (BNA) 2218, 2219 (Dec. 24, 1997) (noting France leading charge at talks on multilateral agreement on investment to include exception to protect cultural industries, just as it had done during Uruguay Round WTO talks).

See A Soft Signal From Iran, NewsweEk, Jan. 19, 1998, at 30; Elaine Sciolino, Seeking to Open a Door to U.S., Iranian Proposes Cultural Ties, N.Y. Times, Jan. 8, 1998, at Al. 
Iraq. Though reinitiating relations with Iran might provide but a modicum of leverage over its objectionable activity, it could well intensify the pressure on Iraq's Saddam Hussein and thus increase his pliancy on a variety of fronts.

The third consideration relevant to the ultimate decision about sanctions against Total is that of linkage. An improvement in relations between the United States and Iran sufficient to rule out sanctions could temper Iran's reaction to the Mideast peace process. Since a wide variety of problems throughout the Persian Gulf region seem related to the pace and direction of that process, any moderation in that respect could prove helpful. But even apart from that, a policy directed at removing obstacles to the development of the natural gas resources in Iran could provide a mechanism for alleviating global climate change. Currently, the United States, the European Community, Japan, and the twenty-six other members of the Organisation for Economic Co-operation and Development are responsible for approximately 50 percent of the world's anthropogenic emissions of carbon dioxide, ${ }^{51}$ the most important greenhouse gas. By the year 2010, because of their reliance on coal, which produces several times as much carbon dioxide as does natural gas, India and China are expected to be the world's two biggest: polluters, accounting for 20 percent of total carbon dioxide emissions. ${ }^{52}$ Only Pakistan separates Iran from India. Therefore, a modus vivendi conditioning a new attitude toward oil and gas investment on a commitment to establish a pipeline connecting consumers in India with suppliers in Iran could prove immensely valuable.

In each case in which an "investment" under the ILSA is determined to exist, the potential for the imposition of sanctions is present. Whether Total's contractual commitment to Iran of September 28, 1997, will result in sanctions involves reflection on many complex and delicate matters. Future instances in which the Act is involved will raise considerations of comparable difficulty. In the end, policy makers can never be certain that the action they choose will be well-advised. Each occasion, however, demands reflection on the broadest range of possibly relevant factors.

REX J. ZEDALIS*

${ }^{51}$ See INTERNATIONAL ENERgy Agency, World ENERgy OUtLook: 1996, at 57-58 (based on 1993 emission figures).

${ }^{52}$ See id.

* Professor of Law and Director, Comparative and International Law Center, University of Tulsa. 